Z Badań nad Książką i Księgozbiorami Historycznymi 2021, t. 15, z. 3

Angela Škovierová

Comenius University, Bratislava, Slovakia

angela.skovierova@fmed.uniba.sk

iD ORCID 0000-0003-1522-9863

http://doi.org/10.33077/uw.25448730.zbkh.2021.672

\title{
Reception of cultural and literary trends in the prints of Slovak authors active in Bohemia at the turn of the $16^{\text {th }}$ century
}

\begin{abstract}
At the turn of the $16^{\text {th }}$ century due to variety of reasons related to the socio-political, educational, and religious situation in Hungary, relatively many natives from the area of today's Slovakia lived and permanently worked in Bohemia and Moravia. These were mostly Protestant scholars, writing and publishing their work in Bohemia. Due to the authors' origin, their works are also considered to be related to Slovakia. This paper illustrates the circumstances of the Slovaks' activity in Bohemia, and selectively presents the inspiration sources (the ancient sources, the Bible, the Renaissance authors) that these scholars used in their work, published largely in Bohemia or intended primarily for the Bohemian market and audience. It also reflects on societal, cultural, religious, and philosophical trends of Humanism.
\end{abstract}

Keywords: humanism - Bohemia and Moravia - Protestant scholars - today's Slovakia inspiration sources - Bible - Renaissance authors 
In research of the history of book culture and literature connected to Slovak cultural and geographical space, scholars, writers, authors of extensive work as well as small occasional prints, and Humanists originating from today's Slovakia constitute a varied and stimulating part. They could have also had ancestors who settled and lived in the territory of today's Slovakia for a longer time, but the authors themselves left the area for various reasons and settled in Bohemia and Moravia; and they were active here permanently and published their work in the local printing houses. This study aims to highlight selected authors from Slovakia or those whose ancestors demonstrably came from Slovakia, and their work in the Bohemian cultural environment during the period of Renaissance and Humanism at the turn of the $16^{\text {th }}$ century (until 1621). It also provides the reflection on the literary, cultural, religious, and philosophical trends of the time in their prints published by Czech publishers or intended mainly for Czech recipients.

Already in the $15^{\text {th }}$ century, mutual business, military, feudal and cultural relations are developing especially between western Slovakia and Moravia. Cultural contacts in this time are represented by the arrival of scribes from Bohemia, meetings, and exchange between members of monastic orders, and also the arrival of Bohemian, Moravian and Silesian preachers to Slovakia. They settled in the borderlands, worked among Slovak Protestants, and spread Czech religious literature and hymnals used in churches in the Slovak territory ${ }^{1}$.

At the turn of the $16^{\text {th }}$ century, we notice a relatively large number of scholars, especially teachers and clergymen originating from today's Slovakia, who worked, lived, and published their work in Bohemia. Based on long-term research, we managed to identify around sixty personalities born or originating in Upper Hungary, or more precisely in the territory of today's Slovakia but who spent some time (sometimes a significant part of their life) in Bohemia or Moravia. The formation of a relatively large community of Slovaks in Bohemia was sparked among other things by the fact that in Slovakia at that time, there was an unprecedented development of education and many schools lead by Protestants offered the youth a level of education sufficient for them to continue studying at a university. However, after 1490 when Academia Istropolitana was closed, there was no university in Slovakia and talented Protestants were forced to study abroad, mostly in Wittenberg and Prague.

Thus, these scholars would start their education mostly at home - in Upper Hungary (or, in today's Slovakia). We allude to Protestants particularly, as a connection between Catholics and the Bohemian territory and their activity there has not yet been thoroughly researched ${ }^{2}$. They would then

1 E. Pauliny, Slovesnost' a kultúrny jazyk Vel'kej Moravy, Bratislava 1966, p. 30.

2 A. Škovierová, Jesseniovi slovenski súčasnici v Čechách. Vzájomné vzt’ahy a kultúrne súvislosti, [in:] Ján Jessenius (1566-1621) L’udia a doba. Medzinárodná vedecká konferencia konaná 8. decembra 2016, ed. M. Gogola, L. Rybár, Bratislava 2017, pp. 72-92. 
continue to study in Bohemian town schools and then get a degree-Bachelor's or Master's - at Charles University in Prague. They would seldom decide to study at a different European university.

A significant role in their decision to study in Prague was played by the linguistic similarity, hence Slovak scholars used a Slovakised form of Czech as their literary language from the end of the $14^{\text {th }}$ century ${ }^{3}$. Another important factor was religious proximity. In the $15^{\text {th }}$ century, Charles University had become Calixtine and after Martin Luther's address until 1620 also Protestant. The university was also close to other reformed churches and had a partial affinity to Calvinism ${ }^{4}$. Slovak Protestants probably created a tradition of leaving to study in Prague, as we often find a member of the same family in Bohemia and Moravia, and many alumni from Charles University supported the younger countrymen in their studies 5 . The alumni from Prague or students returning from their studies abroad through Bohemia often stayed there. They married, found a comfortable work role, and stayed active in Bohemian and Moravian town schools, in manors in service for the local landowners. They would also work as administrators of Bohemian and Moravian parishes. A smaller percentage remained working on a long-term basis at Charles University. These scholars then naturally merged with the Bohemian environment and they worked, wrote, and published there for some time or the rest of their life.

This is a diverse group of personalities. Some are known Humanist educators and authors of comprehensive works in Latin or Czech, others are known only thanks to secondary information from the university registry that would also mention that they publicly performed their bachelor's or master's discourse, or they would be authors of small occasional poetry in Latin. Some of them had an extensive body of work in Latin, intended only for educated recipients from the university and urban environment, others, such as Juraj Tesák Mošovský (approx. 1547-1617), put emphasis on work written in the language of the people and thus created a scope of activity among townspeople and country people.

An integral part of the reformation culture budding in Slovakia and Bohemia was an active embracing of the past, not only ancient times but the overall return to the source and the desire to explore and delve into the culture of the ancient history and the Middle Ages. Understandably, everything was subordinated to the requirements and needs of the reformation ideology ${ }^{6}$. Humanists were pleased to comment, edit, rework or adapt various literary works to the period

3 J. Dorul'a, Slováci v dejinách jazykových vzt'ahov, Bratislava 1977, pp. 34-35.

4 Z. Winter, Děje vysokých škol pražských od secessí cizich národi̊ po dobu bitvy bělohorské (1409-1622), Praha 1897, p. 201.

5 E. Frimmová, Daniel Basilius (1585-1628), Bratislava 1997, pp. 14-16.

6 M. Hamada, Zrod novodobej slovenskej kultúry, Bratislava 1995, p. 16. 
situations - biblical stories, as well as classic works of ancient authors, lateancient and medieval manuscripts, and also the works of their contemporaries.

Protestants centred their literary interests around the Bible and their works frequently feature various citations from psalms and proverbs. Reformation discovers the joy of reading the Old Testament, as the Holy Scripture became a source of lessons and morals for Christian authors. Bible had to be read and interpreted and should have been the basis for sermons; authors of polemic and apologetic manuscripts leaned on biblical statements, mainly the gospels and apostolic letters in their interpretations as arguments. New plays were based on the stories from the Old Testament whereas the proverbs and psalms were becoming the model of poetry. As a direct inspirational source, Old Testament stories predominate in the dramatic works of Pavel Kyrmezer (1530/40-1589), J. Tesák Mošovský and Ondrej Rochotský (c.1583-after 1623). Poets such as Ján Silvánus, Vavrinec Benedikt Nedožerský, or O. Rochotský, who boasted the title of poeta laureatus caesareus ${ }^{7}$, often only take the idea or a quote from the gospel or psalm, which they further develop in verse or incorporate into another work. As an example, in the extensive body of work of O. Rochotský, he made use of the Gospel of John, stories from the Book of Genesis, the Book of Judges, or the Book of Ezekiel. The "unsuccessful" teacher Martin Monkovicenus (1593-1624) ${ }^{8}$ relies in his defensive speech Ultimum vale, sive Oratio Habita Trinchini published in Prague in 1616 on the biblical Book of Kings, psalms, Gospel of Luke, Mark, or Letters of Paul to Timothy. Numerous references to various parts of the Bible can be found in the sermons of J. Tesák Mošovský, in the sermons of Matej Plorantius, and in the apologetic writings Acta concordiae (1580) and Confesio fidei et doctrinae de vera aeterna deitate Jesu Christi $(1585)^{9}$ by P. Kyrmezer.

As well as the Bible, an indisputable inspirational source for all Humanists with their origin tied to the Slovak territory and regardless of their professional orientation or worldview proved to be the works of ancient authors. Verses cited from Virgil's Aeneid are found in M. Plorantius ${ }^{10}$ vernacular sermon, and O. Rochotský's Latin biblical epic about Samson ${ }^{11}$. Virgil was popular among

7 A. Škovierová, Duchovný epos ako zrkadlo doby - Ondrej Rochotský a jeho parafráza biblického príbehu o Samsonovi, [in:] Sunt libri mei... Knihovny ve výchovném procesu novověkého čtenáre, ed. L. Heilandová, J. Pavelková, Brno 2018, pp. 89-97.

8 A. Škovierová, Martin Monkovicenus (1593-1624?) a jeho reč Ultimum vale, sive oratio habita Trinchini [...] vo svetle slovensko-českej akademickej peregrinácie, „Kniha” 2019, pp. 131-139.

9 These two works were published on the territory of today's Slovakia. Probably in Plavecké Podhradie and in Hlohovec. However, they were also intended for Czech / Moravian evangelical recipients.

10 A. Škovierová, Kázeň Mateja Plorantia o ničivom požiari (1613), [in:] Z dejín kázňovej prózy II., ed. E. Brtáňová, D. Soukup, Bratislava 2021 (in print).

11 A. Škovierová, Duchovný epos ako zrkadlo doby..., p. 96. 
Christian Humanists and accepted mainly thanks to his fourth eclogue, in which he predicts the birth of the divine child - according to Christian interpretations this was to be Jesus Christ. Concerning the form and metric system, a favorite inspiration for playwrights were Plautus' and Terence's plays. O. Rochotský in his plays also alludes to the phrase Plaudete cives acta est fabula, which traditionally concluded the ancient plays. Other popular Latin authors included Seneca, Cicero, Ovid, Horace, and others. M. Monkovicenus refers to them in his aforementioned speech Ultimum Vale, Sive Oratio Habita Trinchini. Humanists connected to Charles University thanks to their polyhistoric education and a wide range of interests also devoted themselves to unusual natural phenomena and disasters affecting humanity - comets, earthquakes, plague and fires, etc. They based their interpretations largely on Aristotle, Lucretius, Pliny the Elder, Hippocrates, and others.

Due to the attractiveness of Charles University in Prague for our Protestant students, Slovak literary history also gains several important personalities professors or important university officials, in whose artistic and scientific work we can trace the active reception of European Humanism trends. Some of the most notable of these personalities include professors and later deans of Charles University - V.B. Nedožerský, Ján Jessenius, Daniel Basilius, and Peter Fradelius. In their body of work, depending on the field that was addressed, we notice a direct acceptance of ideas and opinions of significant Protestant thinkers of the period or the impact of aesthetic trends of the time.

In his philosophical, pedagogical, linguistic, or other professional views, one of our most significant and most famous personalities of Humanism and Renaissance was also influenced by the prominent European Protestant thinkers - V.B. Nedožerský (1555-1615). He was a professor and later dean of the Philosophical Faculty of Charles University, as well as a linguist, mathematician, musician, and educational reformer. His interest in linguistic issues gave rise to the first systematic book of the grammar of the Czech language (written in Latin) Grammaticae Bohemicae ad leges naturalis Methodi conformatae et notis numerisque Illustratae ac distinctae libri duo (1603). It was prepared based on linguistically purest literature and spoken language, taking German Humanist scholar and reformation theologist Philip Melanchthon's (14971560 ) and his Latin grammar as an example, as well as drawing inspiration from the book of the grammar of the French philosopher and Humanist Pierre de La Ramée (1515-1572) $)^{12}$.

The influence of Ph. Melanchthon, a representative of the Augsburg Lutheranism is clearly reflected in many works of Martin Rakovský

12 Z. Kákošová, Benedikt Nedožerský, Vavrinec (entry), [in:] Slovník slovenských spisovatelov, ed. V. Mikula [and others], Bratislava 2005, pp. 80-81. 
(1535-1579), who was the most important Humanist poet and a $16^{\text {th }}$ century scholar. His work was renowned beyond the Hungarian territory and falls within the European context. Rakovský was briefly a rector of a school in Žatec and later in Czech cities Žatec and later in Louny . Upon his arrival to Prague from Wittenberg, where he got acquainted with $\mathrm{Ph}$. Melanchthon, he became a member of the Humanist circle around John the Elder from Hodějov ${ }^{13}$.

Czech, as well as European Protestant school systems, were significantly influenced by the education system promoted by Johannes Sturm (1507-1589), an Alsatian educator and reformer. V.B. Nedožerský's school handbook from 1609 followed the educational views of Sturm.

V.B. Nedožerský metrically and strophically formed the first Czech system of poetic metric verse and theoretically accounted for it in an edition of psalm translations or paraphrases Aliquot psalmorum Davidicorum paraphrasis rhytmometrica, lyrico carmine ad imitationem latinorum nunc primum attentata. Zialmowé někteřj w pjsně č̌eské na spůsob werssů latinských wnowě vivedeni, issued in Prague at Juraj Nigrin's printing house in $1606^{14}$. Here we can assume the influence of George Buchanan (1506-1582), the famous Scottish poet and author of paraphrases of David's psalms Paraphrasis Psalmorum Davidis Poetica $(1567)^{15}$, recognized in the community of European scholars especially for his academic excellence and mastery of Latin.

G. Buchanan also wrote two plays and O. Rochotský noticeably used one of them, Iephetes (1580) as inspiration in his plays. In Gedeon and Iosephiados ${ }^{16}$, Rochotský wasn't only inspired by Buchanan's characters, but also he paraphrased his verses.

13 M. Okál, Život a dielo Martina Rakovského. [Vol.:] 1-2, Martin 1979-1983, [online] https:// zlatyfond.sme.sk/autor/103/Martin-Rakovsky\#ixzz6xnb19wwG [accessed 1.7.2020].

14 Knihopis českých a slovenských tiski̊ od doby nejstarší až do konce 18. století. Část V. Písmena $M-O$, č. záznamu 17575, [online] https://aleph.nkp.cz/F/HF5FIUC4S6DY3Y13UH4GSN4GK74HLNB4U86SPTM7NTQJLPE8HB-35817?func=full-set-set\&set_number=130709\&set_entry $=000001 \&$ format $=999$ [accessed 01.07.2020]; E. Frimmová, Žalmy $v$ slovenskej humanistickej a renesančnej poézii, [in:] O prekladoch Biblie do Slovenčiny a do iných slovanských jazykov, ed. J. Dorul'a, Bratislava 1997, p. 99.

15 Psalmorum Davidis Paraphrasis Poetica, Autore Georgio Buchanano Scoto, poetarum nostri saeculi facilè principe. Eiusdem Buchanani tragoedia quae inscrititur Iephetes, Lutetiae : Ex officina Roberti Stephani, Typographi Regij M. D. XXX [1580], [online] https://books.google. sk/books?id=CgBBAAAAcAAJ\&pg=RA1-PA299\&lpg=RA1PA299\&dq=qui +mare+turbidum + Componis, \&source=bl\&ots $=$ JhgSWnjwJf\&sig $=$ ACfU3U2nN1yD7oZY1YfXcms60DnojkjSN Q\&hl=en\&sa=X\&ved=2ahUKEwj07OGd_5XjAhUCU1AKHftKARcQ6AEwB3oECAMQA$\mathrm{Q} \# \mathrm{v}=$ onepage \&q\&f=false [accessed 03.07. 2019].

16 O. Rochotský, Iosephiados comaedia ex Genesis Lib. cap. 39., 40., 41., Pragae : typis Schumanianis, [1607-1608], [44] unnumbered p., 4º, Wrocław University Library (WUL), sign. BU 395682 and O. Rochotský, Gedeon comoedia nova. Cum primis ad usum scholasticum et conditionem temporum accomodata pro noVa ComaeDIa [1606]..., Pragae : typis Schumanianis, [1606], [36] unnumbered p., $4^{\circ}$, WUL, sign. BU 395683. 
D. Basilius from Nemecká L'upča (1585-1628), a mathematician, physicist, astronomer, and professor and educator at Charles University authored several writings, among them discourses in the field of natural sciences, medicine, and biology. As one of the first scholars, he sided with Copernicus' heliocentric opinion. At that time, when research in mathematics, astronomy, and natural sciences was still significantly influenced by the scholastic philosophy of Aristotle and Thomas Aquinas, such opinions were extremely important and revolutionary ${ }^{17}$. One of Basilius's discourses De Iustitia et Iure defends a well-known legal code of Byzantine emperor Justinian I. ${ }^{18}$, which is known today as Corpus Iuris Civilis, and which served as an inspiration for many other Humanists dedicated to legal issues.

J. Jessenius (1566-1621), originally from Turčianske Jaseno was a doctor, politician, philosopher, and another rector of Charles University. He also accepted Copernicus' heliocentric learning and applied some of its elements into his work Zoroaster published in Wittenberg in 1596. He did not emphasize them in terms of astronomy, but in terms of cosmological philosophy, influenced by the Renaissance thinker Francesco Patrizzi (1529-1597) ${ }^{19}$. In addition to political and pedagogical activities, Jessenius achieved fame for the first public autopsy in Bohemia. Although his most important medical writings were issued in 1600 and 1601 in Wittenberg, they created a close connection with Charles University in Prague. An example of his reception of the works of ancient authors and his predecessors and contemporaries is Iinstitutiones chirurgicae (1601). In the introduction of this surgical manuscript, Jessenius naturally refers to Hippocrates' De Officina as well as the famous Italian surgeon Claudio Galen (129-199). He also paraphrases the Italian surgeon Gaspare Tagliacozzi (1546-1599), refers to the Venetian surgeon and anatomist Giovanni Andrea della Croce (1509-1575), an older surgeon from Padua who was the author of several consilia - Bartholomew Mantagnan (1380-1460) and recalls e.g. the surgical tools that he saw in the practice of Padua's surgeon Girolam d'Acquapendente $(1533-1619)^{20}$.

P. Fradelius (1580-1621) was from Banská Štiavnica and was a professor of logic, rhetoric, and poetry as well as the dean and prorector of Charles University. He left behind interesting correspondence and indeed an impressive literary body of work that has not yet been completely captured and properly

17 E. Frimmová, Daniel Basilius (1585-1628)..., p. 54.

18 Ibidem, p. 32.

19 J. Polišenský, J. Jesenský - Jessenius, Praha 1965, pp. 25-26 and pp. 34-35.

20 F. Šimon, Úvod Jesseniových Institutiones chirurgucae, [in:] Ján Jessenius (1566-1621) Ludia a doba. Medzinárodná vedecká konferencia konaná 8. decembra 2016, ed. M. Gogola, L. Rybár, Bratislava 2017, pp. 38-41. 
researched ${ }^{21}$. However, a distinguished piece of his work is the theoretical legal treatise Bonus Iudex (1620), in which the author expresses its views on an ideal judge, and whose dominant part is a paraphrase of the work of the teacher, bookseller and publisher Tomáš Mitis from the Limuz (1514/1523-1591)22.

Part of the university education and a condition of granting a master's or bachelor's degree were public debates or declamations. Discourses were essentially polemic exercises, especially in the sciences taught at the academy. Using mostly the scholastic method (sic et non), statements were confirmed or refuted based on quotes from the Bible, ancient or medieval authors. They searched for an answer to a question (quaestio) raised in the introduction, which was often also the title of the discourse if it was printed. On the other hand, declamation was rhetoric exercise. They were not very long articles developed to be publicly read. Their theme was open. Unlike the discourse, the questions submitted did not need a response nor a discussion. They formed a part of the speaker's eloquence and the content was mostly moral ${ }^{23}$. Master's discourses and declamations were special and mostly occasional. In addition to prominent professors who stayed active for a long time at Charles University, many future teachers of lower school levels started their professional path with discourses. From today's Slovakia, these were e.g. Michal Sudor, Gašpar Sextius, Václav Čičmiansky senior, Adam Proserchomus, Štefan Omasta, Samuel Riczinský, Daniel Lednicius, Ján Bastner and many others ${ }^{24}$. All the discourses reflected current period trends and referred to the Bible and its statements, which were confirmed with other statements by ancient and medieval authorities.

With the onset of the Habsburg rule (1526), Bohemia and other territories were incorporated into a multinational monarchy and the monarch tried to create an absolutist state and was interested in surrounding himself with devoted nobility of higher rank. Therefore, nobility of lower rank and towns began to be suppressed, and thus the rift deepened between towns and nobility and between the lower-ranking nobles and the nobility of higher rank. The development of local conditions in Bohemia varied from Moravia. During the $16^{\text {th }}$ century in Moravia, the politics of the nobility towards the monarch enabled a more free development and more independent decision-making than in Bohemia, which the religious life soon reflected. There was larger religious freedom at some Moravian estates and hence individual religious

21 E. Frimmová, Slovenskí profesori na pražskej univerzite v predbielohorskom období (s prihliadnutím na osobnost' Petra Fradelia), [in:] Město a intelektuálové. Od středověku do roku 1848, ed. O. Fejtová, J. Pešek, Praha 2008, p. 534.

22 E. Frimmová, Recepcia Mitisovho traktátu Bonus Iudex u Petra Fradelia a Viktorína Morávka, „Opera Romanica” 2003, Vol. 4, pp. 157-170.

23 Z. Winter, O životě na vysokých školách pražských knihy dvoje, Praha 1889, p. 287.

24 A. Škovierová, Jesseniovi slovenskí súčasníci v Čechách..., pp. 72-92. 
groups had an easier environment to grow Thus, there was also a certain group of scholars of Slovak origin who were active (mostly not lifelong) in Moravian parishes or in the services of the Moravian nobility ${ }^{25}$. Some of these include the aforementioned P. Kyrmezer, who was a priest and a dean in Uherský Brod, J. Silvánus (1493-1573), an anabaptist preacher in Ivančice in Moravia or M. Plorantius, a Protestant pastor in Lipník nad Bečvou. We could also include Samuel Rochotský, a relative of O. Rochotský, who preached in the Moravian village Prusinovice. Although he hasn't been a writer himself, or rather no work has been preserved, he probably had an interesting and extensive book collection, including the works of significant authors of reformed Protestantism, such as Johannes Oecolampadus, Pierre Viret, Simon Schard, Christoph Hardesheim ${ }^{26}$, or even Ph. Melanchthon and Girolamo Zanchi. These books (and especially dedications and provenance records in them) from the collection of a pastor in Prusinovce document not only his personal and confessional preferences but also the reception of reformed authors in our territory.

Peter Berger was a Protestant pastor and a spiritual administrator that worked for some time in Strážnice and later in Uherský Brod, and was also related to Samuel and Ondrej Rochotský. His son Eliáš Berger similarly to O. Rochotský gained the prestigious title Poeta Laureatus Caesareus, was also an imperial historiographer. In 1612, Berger's Spectator Theater Extemporanei Belli Hungarici Rudolfi II was published in Prague. In this work, he describes from an observer's position the fifteen-year war with the Turks. The (topic) theme of anti-Turkish fights was relatively popular with authors connected to today's Slovakia and working in Bohemia and Moravia. This issue is discussed in the Latin poetry of $\mathrm{O}$. Rochotský where he documents that in the recent past, in 1604 and 1605 Turks and Tatars in Hungary, Austria and Moravia burned down many cities. This is even referred to in a single printed sermon Neděle Prowodnij by M. Plorantius from $1613^{27}$.

Issuing poetry connected to the so-called literary field of Charles University can be considered an indisputable trend of the time. This field was formed by university professors and officials, students and graduates of the utraktivist Charles University, working in various roles in the administration of free royal towns, as well as by utraktivist priests and clergy cooperating with the academy, noble burghers and educated gentry, benefactors, teachers from town

25 J. Daňhelka [and others], Dějiny české literatury. [Vol.:] 1, ed. J. Hrabák, Praha 1959, pp. 323-324.

26 A. Škovierová, Samuel Rochotský a osudy jeho knižnej zbierky, "Studia Bibliographica Posoniensia“ 2021 (in print).

27 A. Škovierová, Kázeň Mateja Plorantia... (in print). 
schools and many others ${ }^{28}$. The poetry was mainly occasional - congratulatory, celebratory, salutatory, consolatory, and other verses were present in almost all printed works published at the turn of the $16^{\text {th }}$ century. However, such occasional poetry could also be published in its respective collection. In many of these, authors with origins that are connected to the territory of today's Slovakia can be found. Even in these verses, the classic Latin education of the authors manifested itself by allusions to ancient realities and literature. The authors (from the many we include at least Ján Kyjanka, David Carolus, Matej and Mikuláš Rakovskí, Juraj Moller and others) mostly delicately combined the ancient elements with a biblical message. They joined the ranks of Humanists, Latin school and university alumni, creating an image of Humanism in Czech and Moravian towns.

In conclusion, social, political, cultural, literary, artistic, or business interactions between Slovaks and Czechs are documented from the oldest times and persist with various modifications. They are reflected in the area of literary, scientific, and artistic creation, in printing and publishing activities of authors from today's Slovakia in Bohemian countries at the turn of the $16^{\text {th }}$ century. If we examine the group of originally Slovak authors as a whole, or if we focus on individual personalities (often little known even until now) e.g. Rochotsky, Monkovicenus, Plorantius, and many others, it is apparent that not only their life but also the content and formal features of their work depict life, culture, and the spiritual climate and penetration of humanism with all its specifics not only into the significant scholarly centre of the time, e.g. Prague, but also into smaller towns where these personalities were working.

\section{Sources}

Psalmorum Davidis Paraphrasis Poetica, Autore Georgio Buchanano Scoto, poetarum nostri saeculi facilè principe. Eiusdem Buchanani tragoedia quae inscrititur Iephetes, Lutetiae:ExofficinaRobertiStephani, TypographiRegijM.D.XXX[1580],[online]https:// books.google.sk/books?id=CgBBAAAAcAAJ\&pg=RA1-PA299\&lpg=RA1PA299 $\& d q=q u i+$ mare + turbidum + Componis,$\&$ source $=$ bl\&ots $=$ Jhg SWnjwJf\&si-

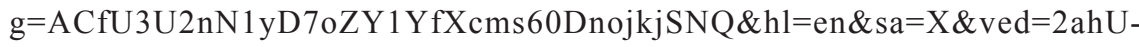
KEwj07OGd_5XjAhUCU1AKHftKARcQ6AEwB3oECAMQAQ\#v=onepage\&q\&f=false [accessed 03.07.2019].

Rochotský O., Iosephiados comaedia ex Genesis Lib. cap. 39., 40., 41., Pragae : typis Schu-manianis, [1607-1608], [44] unnumbered p., 4 , Wrocław University Library (WUL), sign. BU 395682.

28 L. Storchová, Paupertate styloque connecti. Utvářeni humanistické učenecké komunity $v$ českých zemích, Praha 2011, p. 183 and following. 
Rochotský O., Gedeon comoedia nova. Cum primis ad usum scholasticum et conditionem temporum accomodata pro noVa ComaeDIa [1606]..., Pragae : typis Schumanianis, [1606], [36] unnumbered p., 4º, WUL, sign. BU 395683.

\section{Bibliography}

Daňhelka J. [and others], Dějiny české literatury. [Vol.:] 1, ed. J. Hrabák, Praha 1959.

Dorul'a J., Slováci v dejinách jazykových vzt’ahov, Bratislava 1977.

Frimmová E., Daniel Basilius (1585-1628). Život a dielo, Bratislava 1997.

Frimmová E., Recepcia Mitisovho traktátu Bonus Iudex u Petra Fradelia a Viktorína Morávka, „Opera Romanica“ 2003, Vol. 4, pp. 157-170.

Frimmová E., Slovenski profesori na pražskej univerzite v predbielohorskom období (s prihliadnutím na osobnost' Petra Fradelia), [in:] Město a intelektuálové. Od středověku do roku 1848, ed. O. Fejtová, J. Pešek, Praha 2008, pp. 523-546.

Frimmová E., Žalmy v slovenskej humanistickej a renesančnej poézii, [in:] O prekladoch Biblie do Slovenčiny a do iných slovanských jazykov, ed. J. Dorul'a, Bratislava 1997, pp. 94-106.

Hamada M., Zrod novodobej slovenskej kultúry, Bratislava 1995.

Kákošová Z., Benedikt Nedožerský, Vavrinec (entry), [in:] Slovník slovenských spisovatel'ov, ed. V. Mikula [and others], Bratislava 2005, pp. 80-81.

Knihopis českých a slovenských tisků od doby nejstarši až do konce 18. století. Část V. Písmena $M-O$, č. záznamu 17575, [online]

https://aleph.nkp.cz/F/HF5FIUC4S6DY3Y13UH4GSN4GK74HLNB4U86SPTM7NTQJLPE8HB-35817?func=full-set-set\&set_number $=130709 \&$ set_entry $=000001 \&$ format $=999$ [accessed 01.07.2020].

Okál M., Život a dielo Martina Rakovského. [Vol.:] 1-2, Martin 1979-1983, [online] https:// zlatyfond.sme.sk/autor/103/Martin-Rakovsky\#ixzz6xnb19wwG [accessed 1.7.2020].

Pauliny E., Slovesnost' a kultúrny jazyk Vel'kej Moravy, Bratislava 1965.

Polišenský J., J. Jesenský - Jessenius, Praha 1965.

Storchová L., Paupertate styloque connecti. Utvářeni humanistické učenecké komunity věeských zemích, Praha 2011.

Šimon F., Úvod Jesseniových Institutiones chirurgucae, [in:] Ján Jessenius (15661621) L’udia a doba. Medzinárodná vedecká konferencia konaná 8. decembra 2016, ed. M. Gogola, L. Rybár, Bratislava 2017, pp. 37-45.

Škovierová A., Duchovný epos ako zrkadlo doby - Ondrej Rochotský a jeho parafráza biblického príbehu o Samsonovi, [in:] Sunt libri mei... Knihovny ve výchovném procesu novověkého čtenáre, ed. L. Heilandová, J. Pavelková, Brno 2018, pp. 89-97.

Škovierová A., Jesseniovi slovenski súčasníci v Čechách. Vzájomné vzt’ahy a kultúrne súvislosti, [in:] Ján Jessenius (1566-1621) L’udia a doba. Medzinárodná vedecká konferencia konaná 8. decembra 2016, ed. M. Gogola, L. Rybár, Bratislava 2017, pp. 72-92. 
Škovierová A., Kázeň Mateja Plorantia o ničivom požiari (1613), [in:] Z dejín kázňovej prózy II., ed. E. Brtáňová, D. Soukup, Bratislava 2021 (in print).

Škovierová A., Martin Monkovicenus (1593-1624?) a jeho reč Ultimum vale, sive oratio habita Trinchini [...] vo svetle slovensko-českej akademickej peregrinácie, "Kniha" 2019, pp. 131-139.

Škovierová A., Samuel Rochotský a osudy jeho knižnej zbierky, "Studia Bibliographica Posoniensia" 2021 (in print).

Winter Z., Děje vysokých škol pražských od secessí cizích národů po dobu bitvy bělohorské (1409-1622), Praha 1897.

Winter Z., O životě na vysokých školách pražských knihy dvoje, Praha 1889. 